DOI: https://doi.org/10.24144/2409-6857.2021.1(57).127-133

УДК 330.322.1

Мінкович В.Т., Свадеба В.В.,

\title{
ОСОБЛИВОСТІ КРАУДФАНДИНГУ ЯК СУЧАСНОГО МЕТОДУ ФІНАНСУВАННЯ ІНВЕСТИЩІЙНИХ ПРОЄКТІВ
}

\begin{abstract}
У статті розглянуто сутність краудфандингу та особливості його функиіонування, охарактеризовано основні види даного методу фінансування інвестиційних програм і проєктів та визначено його головні специфічні ознаки. Досліджено відомі краудфандингові платформи та проаналізовано показники їх функиіонування. Охарактеризовано механізм роботи краудфандингу, виділено основні його переваги як для інвесторів, так і для власників ідей. Також розглянуто перешкоди розвитку иієї моделі фінансування та запропоновано шляхи вирішення наявних проблем.
\end{abstract}

Ключові слова: краудфандинг, інвестииї, інвестиційні проєкти, стартап-компанії, методи фінансування, краудфандингова платформа, інновачійний бізнес.

Постановка проблеми. Економічні процеси сучасності надають нові виклики для бізнесу, змушуючи генерувати все більше і більше ідей та шляхів розв'язку актуальних проблем і особливо тих, що пов'язані 3 фінансуванням його діяльності. 3 розвитком мережевого суспільства виникає потреба в діджиталізації та застосуванні нових підходів, які надають ширший спектр можливостей для суб'єктів у різних сферах господарювання. Таким, актуальним на часі, методом виступає і краудфандинг, а технологічні новації та простота використання тільки сприяють зростанню його популярності. Адже простіша доступність ресурсу для будь-якої людини 3 бізнес-ідеєю стає перевагою та породжує попит на краудфандингові платформи все більше. На підставі цього можна зробити припущення, що подальший розвиток краудфандингу матиме досить відчутний вплив на економічні та соціальні процеси.

Аналіз досліджень і публікацій. Оскільки поняття краудфандинг має відносно нетривалу історію розвитку, дослідження, пов'язані з ним є небагаточисельними. Окремі аспекти розвитку цього методу знайшли відображення у роботах як вітчизняних вчених, так і закордонних. Зокрема, варто виділити праці: Н. І. Ситника [7], I. О. Хорошилова [9], I. Васильчука [4], О. В. Васильєва [3], П. Діамандіса [5]. Однак питання дослідження ефективності та

СМінкович В.Т., старший викладач кафедри фінансів і банківської справи ДВНЗ «Ужгородський національний університет», e-mail: victoria.minkovych@uzhnu.edu.ua

Свадеба В.В., здобувач вищої освіти економічного факультету ДВНЗ «Ужгородський національний університет», e-mail: svadeba.vita@student.uzhnu.edu.ua доцільності краудфандингу в українських реаліях залишається відкритим та особливо актуальним в сучасних кризових реаліях.

Формулюванні цілей статті. Метою даного дослідження є 3'ясування економічної сутності краудфандингу, визначення його особливостей, переваг та недоліків як сучасного методу фінансування інвестиційних програм і проєктів.

Опис основного матеріалу дослідження. В реаліях сьогодення реалізація будь-якої ідеї потребує залучення коштів, які можуть здійснюватись як традиційними методами, так i навпаки. Одним iз нетрадиційних шляхів одержання фінансової підтримки є краудфандинг, який швидко поширився по всьому світу. Свою популярність він отримав через простий механізм взаємодії між власниками ідеї чи компанії, що потребують коштів, та населенням. Різноманітність проєктів привертає увагу громадян, оскільки пропозиції можуть бути як культурні, так і соціальні, комерційні, політичні, екологічні та ін.

Підходів до трактування сутності краудфандингу є досить багато. Так, на думку Н. I. Ситника [7], краудфандинг - це модель найбільш демократичного фінансування нових чи вже існуючих проєктів за рахунок добровільних внесків численних інвесторів, які отримують за це матеріальну чи нематеріальну винагороду. В той же час, I. О. Хорошилова [9] у своїй праці наводить таке визначення: «краудфандинг - це бізнес на основі інноваційних механізмів і технологій, що задовольняє масу потреб суспільства».

Проте, з нашої точки зору, найбільш точним та тим, що розкриває сутність краудфандингу $\epsilon$ твердження П. Діамандіса [5], а саме, що краудфандинг - це співпраця, кооперація людей, які добровільно надають фінансову підтримку 
стартапу, інноваційному проєкту, ідеї або організації. При цьому така допомога не завжди має альтруїстичний характер.

Сучасна вільна енциклопедія «Вікіпедія» [6], яку може редагувати кожен, публікує наступне пояснення даної категорії: громадське фінансування, англійською краудфандинг (англ. crowdfunding, crowd - "громада, гурт, юрба", funding - "фінансування"), тобто «фінансування громадою» - це співпраця людей, які добровільно об'єднують свої гроші чи інші ресурси разом, як правило через Інтернет, аби підтримати зусилля інших людей або організацій. Громадське фінансування може виконувати різні завдання допомога постраждалим від стихійних лих, підтримка 3 боку вболівальників чи фанатів, підтримка політичних кампаній, фінансування стартап-компаній та малого бізнесу, створення вільного програмного забезпечення тощо.

Тобто, узагальненим $є$ визначення краудфандингу як універсальної моделі взаємодії суб'єктів для «гуртового» вирішення проблем та як механізму економічних відносин, що спрямовані на досягнення конкретної мети. Водночас, нетрадиційними характеристиками краудфандингу $\epsilon$ те, що першочергова роль надається інтернет-ресурсам та те, що кількість учасників реалізації окремого проєкту $\epsilon$ необмеженою.

I хоч поняття краудфандингу $\epsilon$ відносно новим, але незважаючи на це, класифікація даної категорії вже на даний час $є$ досить обширною. Так, дослідниця краудфандингу, автор книги «Готівка з натовпу» Саллі Оутлав [1] виокремлює наступні види краудфандингу:

- краудфандинг на основі безоплатності (Donation-based crowdfunding) - нематеріальні вигоди;

- $\quad$ краудфандинг, заснований на винагороді (Reward-based crowdfunding) - нематеріальні вигоди та інші форми винагород у вигляді продукції, знижок на продукції та ін.;

- краудфандинг через кредитування (Lending-based crowdfunding) - повернення вкладених в проєкт коштів 3 визначеним відсотком в чітко встановлені терміни;

- $\quad$ краудфандинг на основі отримання частки в бізнесі (Equity-based crowdfunding) - дохід від володіння частиною бізнесу, нематеріальні вигоди;

- краудфандинг 3 використанням моделі роялті (Royalty-based crowdfunding), що передбачає майбутній розподіл доходів чи прибутку від реалізації проєкту між інвесторами та його засновником;

- гібридні моделі краудфандингу (Hybrid- based crowdfunding) - це комбінування різноманітних видів краудфандингу в одній моделі фінансування. Комбінування кредитного та краудфандингу на основі частки в бізнесі, коли фінансування із завершенням терміну позики перетворюється в права на частку в фінансованому бізнесі.

Фінансування від населення можуть потребувати не лише громадсько-суспільні проєкти, а й невеликі та середні компанії, що хочуть розвиватися і потребують більше матеріальних ресурсів, порівняно з тим, скільки вони можуть забезпечити самостійно. Отож, суб'єктами процесу краудфандингу можуть виступати, по-перше, інвестори та спонсори, що надають кошти, i яких називають “фандери”, а подруге, пошукачі чи реципієнти капіталу, які $\epsilon$ ініціаторами-засновниками краудфандингового проєкту - "фундери" [4].

Визначаючи особливості краудфандингу варто визначити його специфічні ознаки, що відрізняють дану модель від інших вже традиційних в наш час видів фінансування інвестиційних проєктів, а саме:

$\checkmark$ прямий зв'язок між потенційними інвесторами та тими, що потребують інвестування (без фінансового впливу банків як посередників);

$\checkmark$ процес мікрофінансування, тобто, вкладення невеликих сум в певні проєкти широким колом осіб;

$\checkmark$ відсутність бар'єрів між донорами та об'єктами фінансування, які, наприклад, можуть виникнути через національне регулювання фінансової сфери, структуру національного та міжнародного фінансового ринку, особливості фінансової інфраструктури;

$\checkmark$ залучення до процесу великої кількості як об'єктів соціального інвестування, що пропонують конкретні проєкти, так і суб'єктів, тобто, донорів, які фінансують ці проєкти;

$\checkmark$ ризики можуть бути мінімальними через невеликі залучені суми, але це не змінюе того факту, що краудфандинг, все ж, може виступати як зручний спосіб шахрайства;

$\checkmark$ надання соціальним мережам особливої ролі через утворення нетрадиційної мережевої системи фінансування, де потенційний інвестор та автор проєкту знаходять один одного через соціальні мережі.

Таким чином, для інноваційного бізнесу краудфандинг $\epsilon$ простим та досить вдалим механізмом залучення фінансування. Він надає можливість підприємцю залучити кошти без допомоги банків, бірж чи венчурних фондів, а єдине, що потрібно мати компанії - 
перспективний проєкт і рахунок в банку. Це суттєво спрощує процес залучення грошей. Зазвичай механізм роботи краудфандингу виглядає так [3]:

1) Наявність суб'єкту краудфандингу.

2) Висування певної ідеї суб'єктом.

3) Створення проєкту та розміщення на краудфандинговій платформі.

4) Процес розповсюдження: розповідь друзям, знайомим, однодумцям та потенційним інвесторам про свій проєкт через ЗМI, соціальні мережі чи ресурси платформи.

5) Збір коштів від людей, процес завершення краудфандингової угоди.

6) Реаліація проєкту та винагорода вкладників.

Механізм краудфандингу є більш прозорим та більш доступним для розуміння й застосування пересічними громадянами, ніж інші способи залучення коштів. Перспектива вкладення мізерних коштів та простота процесу здійснення вкладень збільшує кількість потенційних інвесторів. Саме спрощення процедури відбувається за рахунок існування краудфандингових платформ. Це відповідно онлайн платформа, на якій розміщуються ідеї, для яких відбувається збір коштів серед інтернеткористувачів. Як правило, спонсорам гарантується нематеріальна винагорода у вигляді готового продукту або інших подарунків, які мають безпосереднє відношення до проекту. Майданчик бере на себе забезпечення багатьох аспектів, в тому числі фінансових і юридичних, а також допомагає в просуванні i полегшує взаємодію всіх учасників [10].

В сучасних, складних для більшості суб'єктів, умовах господарювання популярність краудфандингової моделі фінансування постійно зростає. В розвинутих економіках вже $\epsilon$ краудфандингові платформи, що стали світовими лідерами серед обсягу залученого фінансування. В теперішній період до них відносять [8]:

$>$ Kickstarter - найбільша i найвідоміша платформа, проєкти - творчі, виробничі тощо, комісія за послуги складає 5\%, комісія платіжної системи 3-5\%, особливостями $\epsilon$ те, що вона $є$ зареєстрованою юридичною особою у США, а винагородою для користувачів зазвичай $\epsilon$ екземпляр продукту/товару, покупка за зниженою ціною.

> IndieGoGo - краудфандингова платформа, заснована на принципах відкритості, прозорості і свободи вибору та дій. Тут немає обмежень за типом проєктів. Також помітною відмінністю $є$ можливість отримати кошти, навіть якщо фінансова ціль компанії не досягнута, а також те, що платформа відкрита для користувачів 3 будьякої точки світу. Комісія за послуги: 5\% за умови $100 \%$ зібраних коштів, 9\% за умови понад 50\% зібраних коштів. Проте відсутня комісія платіжної системи.

$>$ Wemakeit - $\quad$ швейцарська краудфандингова платформа, що здебільшого орієнтована на проекти в сфері IT, музики та видання книг. Винагородою для користувачів $\epsilon$ подарунки, специфічні особливості відсутні. Комісія за послуги складає $10 \%$ за умови $100 \%$ зібраних коштів, а комісія платіжної системи - 4$6 \%$.

$>$ Ulule - французька краудфандингова платформа, нема. Зазвичай орієнтована на проєкти в сфері музики, кіно і відео, спорту, видавництва і журналістики, ремесла, їжі, ігор, технологій, тощо. Специфічних особливостей діяльності не має. Винагорода для користувачів подарунки. Комісія за послуги $-8 \%$ за умови $100 \%$ зібраних коштів, комісія платіжної системи 5\% PayPal.

Попри вже зростаючу конкуренцію в даному виді діяльності, Kickstarter та IndieGoGo протягом останніх років залишаються найуспішнішими краудфандинговими платформами (рис. 1) та іншим майданчикам важко 3 ними конкурувати (хоча окрім наведених вище досить відомими та популярними $\epsilon$ також Rockethub, Fundrazr, Crowdfunder.co.uk), так як на даних платформах представлено досить багато сфер, в яких можна обирати різноманітні проєкти для інвестування.

Так, в залежності від спрямованості представлених проєктів на платформі Kickstarter найбільшу частку займають музика $(8,65 \%)$, фільми (7,78\%), дизайн $(7,56 \%)$ та ігри $(7,51 \%)$. Стосовно IndieGoGO, то фільми на першій сходинці $(3,63 \%)$, музика $(2,6 \%)$, технології $(2,02 \%)$, суспільні потреби $(1,88 \%)$. Ha Fundrazr благодійність має найбільшу частку $(2,69 \%)$, а в Crowdfunder.co.uk - суспільні потреби $(0,74 \%)$ [2].

Також, лідером завершених проєктів на краудфандингових платформах $є$ Kickstarter, де вже зафіксовано завершених і повністю профінансованих проектів 225877 , а частково недофінансованих - 125773 . У IndieGoGo ця кількість становить 280987 та 39291 відповідно. Fundrazr фіксує 12627 повністю фінансово закритих проєктів та 17132 завершених із частково зібраною сумою Crowdfunder.co.uk й 


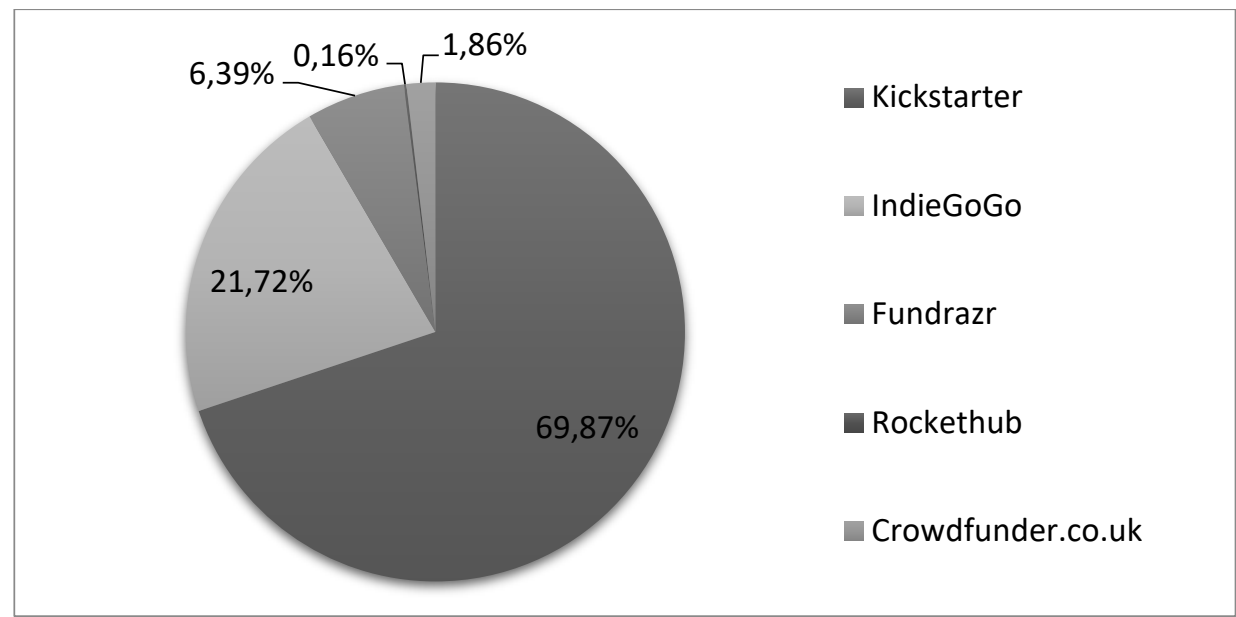

Рис. 1. Структура повністю профінансованих просктів на окремих популярних краудфандингових платформах світу станом на поч. 2020 року [2]

Rockethub не відображають 100\% матеріально забезпечених проєктів, а 3 відносно немалою сумою 21096 та 4070 проєктів відповідно (рис. 2).

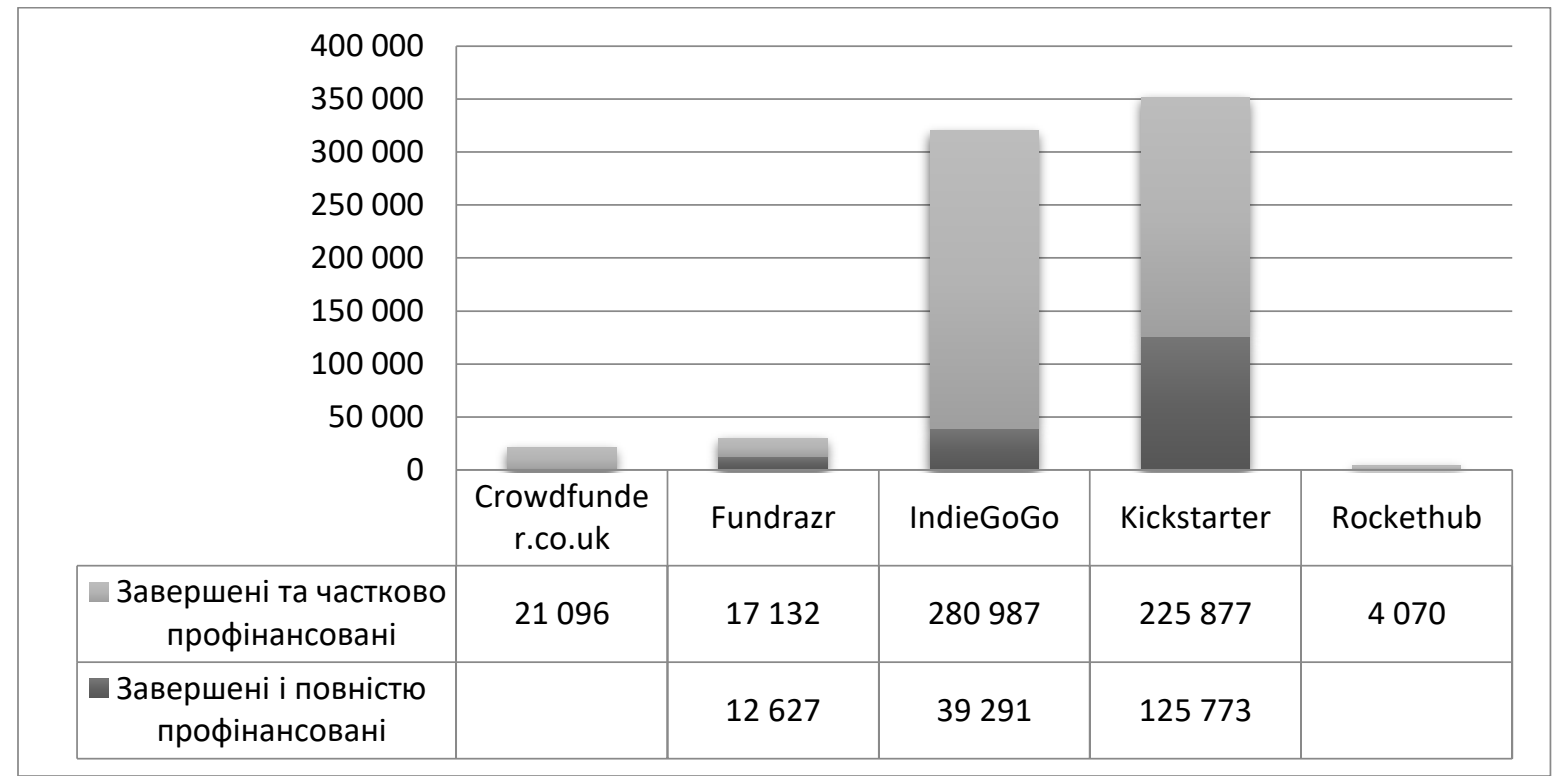

Рис. 2. Кількість повністю та частково профінансованих просктів на відомих краудфандингових платформах світу станом на поч. 2020 року[2]

Що стосується вітчизняного ринку, то для нього краудфандинг хоч і відносно нове поняття, але в той же час можна спостерігати досить швидкі темпи розвитку його популярності. Адже протягом останніх років вітчизняних платформ стає все більше та профінансованих на них проєктів також. Так, серед українських краудфандингових платформ найвідомішими $€$ [8]:

1) «Спільнокошт» - займається проєктами, що пов'язані 3 економікою, подорожами, транспортом, освітою, соціальним бізнесом тощо.
Винагорода для користувачів тут у форматі подарунків. Комісія за послуги $10 \%$ за умови $100 \%$ зібраних коштів або понад $50 \%$, визначних особливостей нема.

2) $\mathrm{Na}$-Starte - представляє проєкти соціальні та комерційні, для користувачів передбачено подарунки в залежності від обсягу вкладених коштів. Комісія за послуги складає $8 \%$ за умови $100 \%$ зібраних коштів, іншого не передбачено. Платіжна система в даному випадку - без комісії.

3) RazomGO - проєкти в сфері дизайну, ігор, технологій, освіти, фото й відео, музики, науки, 
соціальних подій, здоров'я й т.п. Винагорода для користувачів: майстер-класи або подарунки в залежності від суми вкладених коштів. Комісія за послуги становить $8 \%$ за умови $100 \%$ зібраних коштів, $15 \%$ - якщо зібрано більше $50 \%$. Платіжна система комісії тут не передбачає.

Отже далі варто детальніше виокремити переваги використання такого методу фінансування інвестиційних програм і проєктів як краудфандинг саме для потенційних інвесторів. До них можна зарахувати наступне:

1) Велика кількість різноманітних ідей та бізнес-проєктів. Різноманітність дозволяе кожному конкретному інвестору вибрати той напрямок чи сферу, яка йому цікава та в якій він вбачає перспективу успішного розвитку. Це може бути благодійність, кіноіндустрія, інформаційні технології, розробка інноваційних продуктів будь-що.

2) Можливість інвестування невеликих сум. Зазвичай, бажаючи допомогти комусь чи посприяти розвитку чогось справді соціальнозначимого, люди вважають, що невеликі інвестиції нічого не змінять і нема сенсу їх надавати. Краудфандинг, який в своїй початковій ідеї створювався як засіб, що об'єднує незначні інвестиції багатьох людей, вирішує цю проблему.

3) Диверсифікація вкладень. Вкладаючи невеликі кошти в різні інвестиційні проєкти, стартапи та бізнес-ідеї, потенційний інвестор може знизити ризики фінансових втрат до мінімального рівня.

Але, оскільки суб'єктами краудфандингу, окрім інвесторів, виступають і так звані “фундери”, тобто, реципієнти капіталу, пошукачі, то доцільним вважаємо також виділити головні переваги цього нетрадиційного методу залучення коштів і для розробників ідей, а саме:

1) $\mathrm{He}$ ускладнена процедура одержання необхідних для реалізації окремого проєкту обсягів фінансових ресурсів. Адже часто буває так, що геніальні ідеї так і не втілюються в життя, залишившись на етапі пошуку фінансування. А за допомогою даного методу інвестори готові надавати кошти для реалізації унікальних проєктів, ще й з можливістю отримати прибуток в майбутньому.

2) Відсутність необхідності отримання банківського кредиту i послідуючого його повернення з відсотками. Адже не завжди і не всі бажаючі мають можливість отримати банківський кредит для реалізації своєї ідеї, особливо значну суму, без забезпечень. Очевидно, що прибуток майбутнього періоду не може виступити гарантією для банку. В той же час при краудфандингу інвестиції та й відсотки по ним після реалізації проєкту не повертаються. А в деяких формах краудфандингу навіть відсутня пряма матеріальна віддача.

3) Відсутність численних посередників між розробниками та групою інвесторів. Адже наявність одного надійного посередника у вигляді вже певний час існуючої та надійної краудфандингової платформи дозволяє надати значимість проєкту та й збільшити рівень довіри до нього. При цьому розробник платить комісію чи відсоток від зібраної суми тільки власникам платформи.

В той же час при всіх наявних перевагах моделі краудфандингу, варто визначити й ряд недоліків, які перешкоджають розвитку даного напрямку, як в Україні, так і у світі загалом. До них врахуємо наступні:

- Фінансові втрати, які можуть спіткати кожного інвестора у випадку, якщо розробник не зможе в підсумку своєї діяльності реалізувати профінансований проєкт успішно. Адже проєкти, в які інвестуються кошти, не завжди можуть бути успішними. У більшості випадків це пов'язано із недостатнім досвідом в молодих розробників i відсутністю професійної оцінки рентабельності проєкту.

- До даного часу існують платформи, де взагалі відсутня перевірка презентованих інвестиційних проєктів, стартапів та бізнес-ідей. Фактично, це означає, що будь-яка людина, бажаюча збагатитись особисто і не плануюча реалізувати ніякі обіцяні проєкти, може використати даний спосіб 3 метою недобросовісного збагачення. Так, без належної та ретельної перевірки наданих документів та інформації про проєкт, потенційні інвестори можуть стати жертвами шахраїв.

- Відсутність в інвесторів можливості подальшого контролю за переданими грошовими коштами на реалізацію інвестиційного проєкту. Цей недолік передбачає аж дві небезпеки. 3 одного боку, гроші інвестора можуть бути використані не за цільовим призначенням i перенаправлятись на фінансування сполучених чи діаметрально протилежних ідей на розсуд реципієнта. 3 іншого боку, відсутність юридичного регулювання фінансових потоків відповідних платформ 3 боку держави може призвести до фінансування міжнародного екстремізму, тероризму та інших заборонених законом видів діяльності.

Таким чином, проаналізувавши зазначені переваги та недоліки краудфандингу, варто все ж відмітити, що цей спосіб залучення фінансових ресурсів містить в собі більше позитивних можливостей, аніж загроз, тому необхідно 
розглядати варіант проведення змін чи покращень для його ефективнішого функціонування та розвитку. До таких перспективних рекомендацій віднесемо наступні:

\$ подальше якісне розроблення актуального та вдосконалення вже існуючого законодавства, що могло б якісно регулювати дану сферу взаємовідносин контрагентів, формування чітких та прозорих умов здійснення краудфінансування;

\$ забезпечення можливості формування різних видів/типів/форм краудплатформ, спеціально створених консалтингових агентств, що могли б супроводжувати та підтримувати представлені проєкти, надавати консультаційні послуги, інформувати про колективне фінансування в мережі Інтернет, а це своєю чергою призвело б до якісного розвитку та розбудови краудфандингової інфраструктури;

* співфінансування справді перспективних проєктів громадськими структурами для підтримки подальшого розвитку краудплатформ на початкових етапах їх створення, запуску та популяризації;

\# підвищення ступеня обізнаності населення в нюансах та можливостях, які надає метод колективного фінансуванні за допомогою інформаційного супроводу, ЗМI, соціальних мереж, формування культури краудфандингу для створення позитивного іміджу серед населення, 3 метою залучення більшої кількості як інвесторів, так і по шукачів i в результаті можливості реалізації більшої кількості соціально-значущих проєктів та ідей;

забезпечення державою мінімізації ризиків для інвесторів непрофесійного типу через наявність можливостей розгалуження обсягу своїх інвестицій;

залучення до інвестування різних типів приватних інвесторів шляхом вдосконалення та модернізації методів переказу та збору коштів, дотримання принципу прозорості у використання зібраних фінансових ресурсів;
\# стимулювання

розвитку якісної, ефективної та водночас простої комунікації між розробниками проєктів та потенційними інвесторами.

Висновки i перспективи подальших досліджень. Таким чином, в результаті проведеного дослідження, можемо зробити висновок, що незважаючи на все ще наявні недоліки, краудфандинг справді викликає зацікавленість у бізнес-спільноти, адже забезпечує можливість реалізаторам новітніх ідей та стартап-компаніям скористатися зручним, а інколи i єдиним, способом залучення фінансування для реалізації своїх подальших планів розвитку або окремих проєктів. Окрім цього, в сучасних умовах краудфандинг функціонує як загальноприйнятий інструмент, який швидко розвивається та набуває поширення в цілому світі як альтернативний або додатковий варіант залучення інвестицій. А для підвищення його ролі в українських реаліях необхідним $\epsilon$ формування чіткого та гнучкого до змін законодавства, стимулювання залучення в дану сферу різних типів приватних інвесторів, забезпечення мінімізації ризиків для інвесторів непрофесійного типу, створення та поширення культури колективного фінансування серед населення України. Реалізація вищезгаданих дій зможе стимулювати розвиток ринку краудфандингу в Україні та дасть поштовх до зростання економіки в умовах розвитку мережевого суспільства.

Так, в контексті якісного розвитку діджиталізації в останні роки й в Україні також, перспективу подальших досліджень вбачаємо у визначенні ефективних та якісних способів розвитку фандрейзингу в нашій країні та можливостей використання даного процесу вітчизняними суб' єктами господарювання, що може полегшити та забезпечити більшу ефективність їх діяльності в сучасний кризовий період.

\section{ПЕРЕЛІК ВИКОРИСТАНИХ ДЖЕРЕЛ}

1. Outlaw S. Which Type of Crowdfunding Is Best for You? URL: https://www.entrepreneur.com/article/228524 (дата звернення 10.02.2021).

2. Platforms stats \& analytics. TheCrowdDataCenter : website. URL: https://www.thecrowdfundingcenter.com/data/platforms (дата звернення 18.01.2021).

3. Васильєв О.В., Матющенко С.С. Краудфандинг - сучасний інструмент фінансування розвитку інтелектуального капіталу. Економічна наука, 2016. №18. С. 36-40.

4. Васильчук I. Краудфандинг і краудінвестинг як фінансові інвестиції. Ринок иінних паперів Украӥни, 2013. № 11-12. С. 59-67.

5. Діамандіс П., Котлер С. Переможець. Як досягти колосального успіху і вплинути на світ. Київ : К. Fund, 2016. $253 \mathrm{c}$.

6. Краудфандинг. Вільна енциклопедія «Вікіпедія» : веб-сайт. URL: 
https://uk.wikipedia.org/wiki/\%D0\%9A\%D1\%80\%D0\%B0\%D1\%83\%D0\%B4\%D1\%84\%D0\%B0\%D0\%B

$\mathrm{D} \% \mathrm{D} 0 \% \mathrm{~B} 4 \% \mathrm{D} 0 \% \mathrm{~B} 8 \% \mathrm{D} 0 \% \mathrm{BD} \% \mathrm{D} 0 \% \mathrm{~B} 3$ (дата звернення 19.02.2021).

7. Ситник Н. I. Краудфандинг: нові можливості та тренди. Науковий вісник Херсонського державного університету, 2018. Випуск 31. С. 187-192.

8. Спориш К. Огляд 7 краудфандингових платформ. URL: https://buduysvoe.com/publications/oglyad-7kraudfandyngovyh-platform (дата звернення 18.01.2021).

9. Хорошилова І. О. Краудфандинг як шлях залучення коштів. Вісник НТУ «ХПI», 2018. № 19. С. 6063.

10.Що таке краудфандингова платформа? «Дія.Бізнес» : онлайн-платформа. URL: https://business.diia.gov.ua/handbook/finansovij-menedzment/so-take-kraudfandingova-platforma (дата звернення 10.02.2021).

\section{REFERENCES}

1. Outlaw, S. (n.d.). Which Type of Crowdfunding Is Best for You? Retrieved from: https://www.entrepreneur.com/article/228524 [in English].

2. Platforms stats \& analytics. TheCrowdDataCenter: website. (n.d.). Retrieved from: https://www.thecrowdfundingcenter.com/data/platforms [in English].

3. Vasyliev, O.V., \& Matiushchenko, S.S. (2016). Kraudfandynh - suchasnyi instrument finansuvannia rozvytku intelektualnoho kapitalu [Crowdfunding - a modern tool for financing the development of intellectual capital]. Ekonomichna nauka - Economic Science, 18, 36-40 [in Ukrainian].

4. Vasylchuk, I. (2013). Kraudfandynh i kraudinvestynh yak finansovi investytsii [Crowdfunding and crowdfunding as a financial investments]. Rynok tsinnykh paperiv Ukrainy - Ukrainian securities market, 11-12, 59-67 [in Ukrainian].

5. Diamandis, P., \& Kotler, S. (2016). Peremozhets. Yak dosiahty kolosalnoho uspikhu i vplynuty na svit [Winner. How to achieve tremendous success and influence the world]. Kyiv: K. Fund [in Ukrainian].

6. Kraudfandynh [Crowdfunding]. (n.d.). Vilna entsyklopediia «Vikipediia» - Free encyclopedia «Wikipedia». Retrieved

from: https://uk.wikipedia.org/wiki/\%D0\%9A\%D1\%80\%D0\%B0\%D1\%83\%D0\%B4\%D1\%84\%D0\%B0\%D0\%BD\%D0\%B4 $\% \mathrm{D} 0 \% \mathrm{~B} 8 \% \mathrm{D} 0 \% \mathrm{BD} \% \mathrm{D} 0 \% \mathrm{~B} 3$ [in Ukrainian].

7. Sytnyk, N.I. (2018). Kraudfandynh: novi mozhlyvosti ta trendy [Crowdfunding: new opportunities and trends]. Naukovyi visnyk Khersonskoho derzhavnoho universytetu - Scientific Bulletin of Kherson State University, 31, 187-192 [in Ukrainian].

8. Sporysh, K. (n.d.). Ohliad 7 kraudfandynhovykh platform [Overview of 7 crowdfunding platforms]. Retrieved from: https://buduysvoe.com/publications/oglyad-7-kraudfandyngovyh-platform [in Ukrainian].

9. Khoroshylova, I.O. (2018). Kraudfandynh yak shliakh zaluchennia koshtiv [Crowdfunding as a way to raise funds]. Visnyk NTU «KhPI» - Bulletin of NTU «KhPI», 19, 60-63 [in Ukrainian].

10. Shcho take kraudfandynhova platforma? [What is a crowdfunding platform?] (n.d.). «Diia.Biznes»: onlainplatforma - «Action.Business»: online platform. Retrieved from: https://business.diia.gov.ua/handbook/finansovijmenedzment/so-take-kraudfandingova-platforma [in Ukrainian].

Отримано 15.02.2021 